\title{
Analysis of the Key Issues of Enterprise Management Innovation
}

\author{
Wenjuan Zhou \\ Department of Economic Management, Sanmenxia Polytechnic, Sanmenxia, 472000
}

\begin{abstract}
Keywords: Enterprise management innovation; Information-based management; Development history; Being geared to international standards
\end{abstract}

\begin{abstract}
Management is the cornerstone for the enterprise development, and innovation is the driving force behind the enterprise progress, and also the decisive factor for modern enterprises to achieve leapfrog development and steady growth of profit. In the increasingly fierce market competition, the business managers must pay attention to the enterprise management innovation, penetrate innovation into all aspects of enterprise management, and use innovation theory as a guide to continuously enhance the efficiency of enterprise management, survival in the change, and develop in the innovation. This paper explores the necessity of innovation management and the present developmental situation and the existing problems of domestic enterprises, and gives suggestions for those problems. In addition, this paper also uses the case of a diesel engine factory in Shandong to study the enterprise management innovation.
\end{abstract}

\section{Introduction}

As the networking information technology becomes the mainstream of the current society, domestic and international economic globalization has an unprecedented development driven by science and technology. At the same time, the innovation of methods for enterprise management and improvement of management system have also become the key to determine whether modern enterprises can keep up with the era development. The concept of innovative enterprise management began in 1980 or so, with the representative of the "enterprise management revolution" in Japanese manufacturing industry; meanwhile the advanced enterprises in the United States, Europe and so on also launched on the reform of the organizational structure for production, enterprise management pattern and ideas. Enterprise innovation management has gradually become an important research field to achieve sustainable development of advanced enterprises at home and abroad. Domestic large and medium-sized enterprises are now in an important stage of overall change. For the domestic traditional enterprises, in order to switch from the previous planned economy to the current commodity economy, they need not only to seize the upcoming great opportunity, but also to prepare to meet the future challenges, so as to achieve the healthy, rapid and sustainable enterprise development. A sound management mechanism must be established for enterprise innovation and development to improve the competitiveness of enterprise in the market. To this end, this paper starts from the innovative development of domestic enterprises and the main problems in the innovative development, explores the specific approaches for domestic enterprises to perform management innovation, hoping to give domestic enterprises some inspiration in the system and management innovation.

\section{Several Important Stages of Enterprise Management Innovation}

The Enlightenment Stage with Formation of Innovative Management Concept [1]. From the implementation of reform and opening up in 1978 to 1990, many enterprises in this stage gradually began to pay attention to the transition from labor-intensive production mode to managerial mode, and focus on the reform of production management, contract management, leasing management and property management, and encourage to establish the basic ideas of self-management and being responsible for their losses, laying the foundation to further improve the enterprise management innovation. 
Innovation Stage of Enterprise Management System. This stage mainly begins from 1985 to the end of last century. The emphasis of this stage is to promote the separation of enterprise and government, namely the separation of two rights, thus promoting enterprises to make a step towards the commodity economy era. Since then, most domestic enterprises continue to establish the management system of self-management and self-financing. The representatives of this stage are the enterprises in Pearl River Delta region and the Yangtze River Delta region, whose reform and innovation promote the domestic individual economic system-based enterprises to create an unprecedented economic prosperity and rapid development.

Integration Stage of Domestic and Western Enterprises. This stage mainly starts from 1990 to the end of the 20th century. In this stage, the current enterprise management system is gradually formed; the state-owned enterprises achieve rapid transformation and development in the management system reform of this stage, and gradually move towards the world. In order to realize the transformation to the modern enterprise, many state-owned enterprises have devoted to the transformation of various business models, and are constantly docked with the international market. For example, the famous companies of Haier and Changhong and other enterprises have entered the global market.

The stage of Chinese Enterprises being in Line with international Business. From China's formal accession to the international trade market at the beginning of this century, China's enterprises have entered a new stage of development, and the internationalization of enterprises continues to influence the market experience mode of enterprises. At the same time, domestic enterprises have also made outstanding changes; for example, Haier Group established production bases in the United States, domestic enterprises invested in Vietnam, Shanghai Baosteel collaborated with Australian steel enterprises, etc. These have shown that the domestic enterprises have been highly involved in the international markets. At the same time, the antidumping innovative ideas, mergers and acquisitions and brand awareness in the process of enterprise management have been unprecedentedly developed.

\section{Analysis of the Current Situation and Problems of Enterprise Management Innovation}

In order to analyze the current situation and problems of domestic enterprise management innovation, a questionnaire survey was conducted, and the results are showed in Table 1 below:

Table 1 Survey of innovative management status of well-known enterprises in China

\begin{tabular}{|c|c|c|c|c|}
\hline & $\begin{array}{l}\text { Preparation of } \\
\text { management } \\
\text { innovation }\end{array}$ & $\begin{array}{l}\text { Methods of } \\
\text { management } \\
\text { innovation }\end{array}$ & $\begin{array}{l}\text { Aims of } \\
\text { management } \\
\text { innovation }\end{array}$ & $\begin{array}{l}\text { Organization } \\
\text { of } \\
\text { management } \\
\text { innovation }\end{array}$ \\
\hline China Resources & $\triangle$ & $\Delta$ & $\Delta$ & / \\
\hline Wanda Group & $\Delta$ & $\boldsymbol{\Delta}$ & $\boldsymbol{\Delta}$ & $\boldsymbol{\Delta}$ \\
\hline Vanke & $\Delta$ & $\Delta$ & $\boldsymbol{\Delta}$ & $\Delta$ \\
\hline $\begin{array}{l}\text { China Poly Group } \\
\text { Corporation }\end{array}$ & $\triangle$ & $\Delta$ & / & $\Delta$ \\
\hline $\begin{array}{l}\text { China Merchants } \\
\text { Bank }\end{array}$ & $\triangle$ & $\boldsymbol{\Delta}$ & / & $\Delta$ \\
\hline $\begin{array}{l}\text { Shanghai General } \\
\text { Motor }\end{array}$ & $\Delta$ & $\boldsymbol{\Delta}$ & $\Delta$ & / \\
\hline Huaxia Group & $\boldsymbol{\Delta}$ & $\boldsymbol{\Delta}$ & $\Delta$ & $\Delta$ \\
\hline
\end{tabular}

Note: $\boldsymbol{\Delta}$ indicates fully completed ; $\Delta$ indicates not fully completed, / indicates not implement

Analysis of the Current Situation of Enterprise Management Innovation. After about 30 years of reform, innovation and development, the domestic enterprises continually adapt to the 
modern commodity economy and international market environment, achieving the innovation in production technology, management and other aspects. In recent years, domestic enterprises have gradually realized the informatization and internationalization[2,3]. During the rapid changes of economic system and enterprise management model, the domestic enterprises have made remarkable achievements in innovation, but at the same time, they are also facing with challenges from all sides. From Table 1 we can see that, the overall management level of enterprises in China and their innovative ideas have been greatly improved, and they start to integrate the concept of market and competition into the enterprises management. They especially put lots of efforts into making strategic objectives, management mechanism and other aspects. From brand value to internationalization, China's enterprises have made remarkable achievements in innovation management. Through the investigation on innovation in production management of modern enterprise in recent years, it has been found that there are many problems in the process of innovation, such as the non-action in the management innovation of many enterprises and the problem of inertia, which are the main manifestations for the failure to meet the requirements of the current enterprise innovation management. Therefore, the comprehensive development of scientific innovation management is the most important approach to solve the existing problems.

\section{Analysis of the Key Issues in the Current Enterprise Management Innovation}

Issues of Management Model and Management Philosophy[4]. For example, the lack of initiative and enthusiasm in the current enterprise innovation management makes the enterprises fall behind the advanced enterprises in the competition in international market. Lack of scientific management concept as guidance, and unscientific development of innovative ideas lead to the setbacks in enterprise management, and the wrong guiding ideology directly results in the failure of enterprise innovation management. In addition, due to the impact of traditional ideas, many enterprises emphasize on experience-based management, lacking the innovative thinking.

Issue of Irrationality in Development of Strategic Policy. Through survey on most domestic enterprises, it can be found that unscientific strategic policy of most enterprises led to the unreasonable plan of business development, resulting in the failure of innovation in enterprise; the strategic policy of enterprises is not associated with the current domestic and foreign environment for enterprise innovation and development[5]. In addition, the unreasonable strategic policy and estimate of enterprise development will also lead to the failure of innovation management; the deficiency in core competence of modern domestic enterprises management results in the failure in adapting to the development of innovative management model. The absence of scientific idea and connotation for value creation in the planning of strategic target disconnects the enterprise innovation and the actual needs.

Issue of Faultiness in Organization Structure[6-7]. At present, many large and mediumsized enterprises in China have reformed the organizational structure and form of enterprise management. The enterprises have constructed the organizational structure model of modern company management and clarified the functional department, position and responsibility system of the organization. However, due to the faultiness of functional division and content of management in organizational structure of enterprises, the enterprise modernization management is still looking forward to further transformation. For example, the asset management system of the state-owned enterprises is still imperfect, and state-owned assets are still in the form of noncirculation, which accounts for a large proportion; enterprise management system is unsound, which still follows the traditional management and organization model and is not conducive to the rational allocation of enterprise resources; the construction of organizational form of leadership in the enterprises is no standard and unscientific. For example, the decision-making and administrative implementation is still not separated in many state-owned enterprises, resulting in adverse effects on enterprise management. In addition, the organizational structure of enterprises is still not systematic in the aspects of incentive mechanism and supervision mechanism. 
Issue of Enterprise Information Construction. At present, most domestic enterprises are still in the initial stage of the informatization management. From the point of enterprise itself, the traditional concept is the main cause of stagnation in enterprise informatization management. From the point of enterprise technology level, because the domestic informatization management is just in the initial stage, step by step exploration is needed in terms of experience and practice; besides, the backwardness of domestic technology lead to failure in establishing the own informatization management system of enterprise.

From the point of current social environment for domestic enterprises, the emphasis on the informatization management of domestic modern enterprises laid by government agencies and relevant departments is not enough, and enterprises fail to recognize its importance. Many enterprises do not establish informatization management system in order to reduce cost expense.

In order to achieve a comprehensive development, and possess competitiveness in the current social environment, the enterprises must establish a complete pattern of informatization management, which requires the government and other departments to guide enterprises to recognize the importance of informatization management system for the development of modern enterprises, and help enterprises in the terms of funds and implementation.

\section{Proposals for Enterprises to Achieve Innovation Management}

Enhance the Emphasis on Strategic Policy. Scientific strategy for enterprise development is the key to fulfill the modern enterprise management innovation; its content is directly related to the future development direction of the enterprises. With the integration of current domestic and international market and rapid changes in the current social environment, in order to achieve scientific, stable and sustainable development, enterprises must innovate their development strategy with long-term development direction and goals, and find a way suitable for enterprise selfdevelopment with a view to the global market.

Create "Ecological Mode". To create an ecological mode of enterprise management for modern enterprise sustainable development, we can first guide enterprises to transform backward management in today's increasingly fierce and changeable market competition, and to find the ecological mode suitable for enterprise development through cooperation with advanced enterprises, learning and competition, ensuring that the development of enterprises can keep pace with the advanced enterprises with the same goal and value ideas. In addition, the enterprise should overall adopt the management mode for green and sustainable development. The enterprises are required to be consistent with the trend of sustainable development. When implementing the management planning, modern enterprises should not only take into account their economic development, but also focus on the impact of their production and development on the society and the surrounding environment, so as to meet the standards and requirements of environmental protection and achieve the green enterprise management.

Adjust the Organizational Structure of Enterprises. The organizational form and structure of the enterprise should be comprehensively adjusted and innovated. In order to improve the organizational structure, enterprises should achieve the delayering of the organizational structure, that is the innovation in traditional organizational structure mode, and promote the top-down adjustment for traditional organizational mode. Those dispensable management, functional departments and lines should be deleted and compressed, and the original organizational structure should be transformed into a structure with a simple form, quick trans information and strong accountability, thus achieving flexibility, simple and clear form and high efficiency in the process of enterprise management.

Improving the diversity of enterprise organizational structure can not only enhance the mobility of enterprises to the current social environment, but also promote the optimization and innovation in information management, target management and manpower management of enterprise management, thus forming a new internal resource management system with dynamic management. Modern resources management of enterprise is realized through the optimization of organizational management system. 
Enterprises need to build a learning organizational structure. The important principle for innovation and optimization of current enterprise organization is to achieve a common purpose through the organization management; hence for the members of the organizational structure, establishing a common self-learning management organizational structure can not only help members to achieve a common management objective, but also organize members to use common management methods and modes, thereby enhancing the production management efficiency. For example, the US management experts have suggested that, in order to establish a learning organization structure, enterprises should strengthen the integrity of the organization, and promote learning of members. The structure can be built by specific approaches including comprehensive optimization and innovation of the organization based on the member selflearning, change in the traditional thinking, setting common goals and the basic content of common learning.

Strengthen Technology and Advanced Management. For establishing an integrated technology management system, the enterprises firstly should regard technology as an important product to the market. In the process of technology management[8], enterprises should make innovations in production process, technology, quality, progress and cost and such aspects. For example, enterprises can set up their own technical team through building a technical talent bank. The advanced nature of enterprises should be based on the modern developed Internet systems. Enterprises can obtain new ideas, information technology, and management mode globally to maintain their advanced nature.

Speed up the Pace of Institutional Innovation. The innovation of enterprise management mode is inseparable from the innovation of enterprise system. The innovation of enterprise system can effectively promote the management innovation, and also can help enterprises to allocate resources scientifically under the condition of modern international market. The scientific enterprise system is based on the self-management, self-financing and self-innovation of the modern enterprise. The establishment of scientific and comprehensive system is the key to realize the rational allocation of the enterprise resource, the market industrial structure, the market competitiveness, the incentives mechanism for managerial personnel and highly efficient production and other aspects. Scientific institutional innovation can help modern enterprises to achieve comprehensive management innovation and provide the impetus for innovation. Therefore, in order to achieve the innovation of management mode, the modern enterprise must fully deepen the innovation and reform of system management. For example, enterprises can create a modern management system through reform of the equity and dividend policy, salary system, and innovation of promotion mechanism and such.

\section{Case of Enterprise Management Innovation—a Diesel Engine Factory in Shandong}

The diesel engine factory in Shandong was established in 1945, which is a state key manufacturing enterprise. At present, it mainly produces diesel engines for agricultural machinery and equipment, engineering equipment, and transportation equipment, etc. Since the reform and opening up, this enterprise has completed all the reforms, and listed in Hong Kong in 2004. In recent years, this enterprise has rapidly improved its management level, and gradually become the leading enterprise in diesel engine industry.

There are many problems in the process of restructuring of enterprise; for example, the enterprise is facing enormous pressure due to the increasingly fierce market competition, and low products sales and overall professional and technical level of staff from 1998 to 1999. To this end, the enterprise carried out the innovation in corporate philosophy and brand promotion, and reform of ownership system in terms of corporate equity and dividend policy, and other aspects of measures. The innovative management mode of this enterprise is showed in Fig. 1 below. 


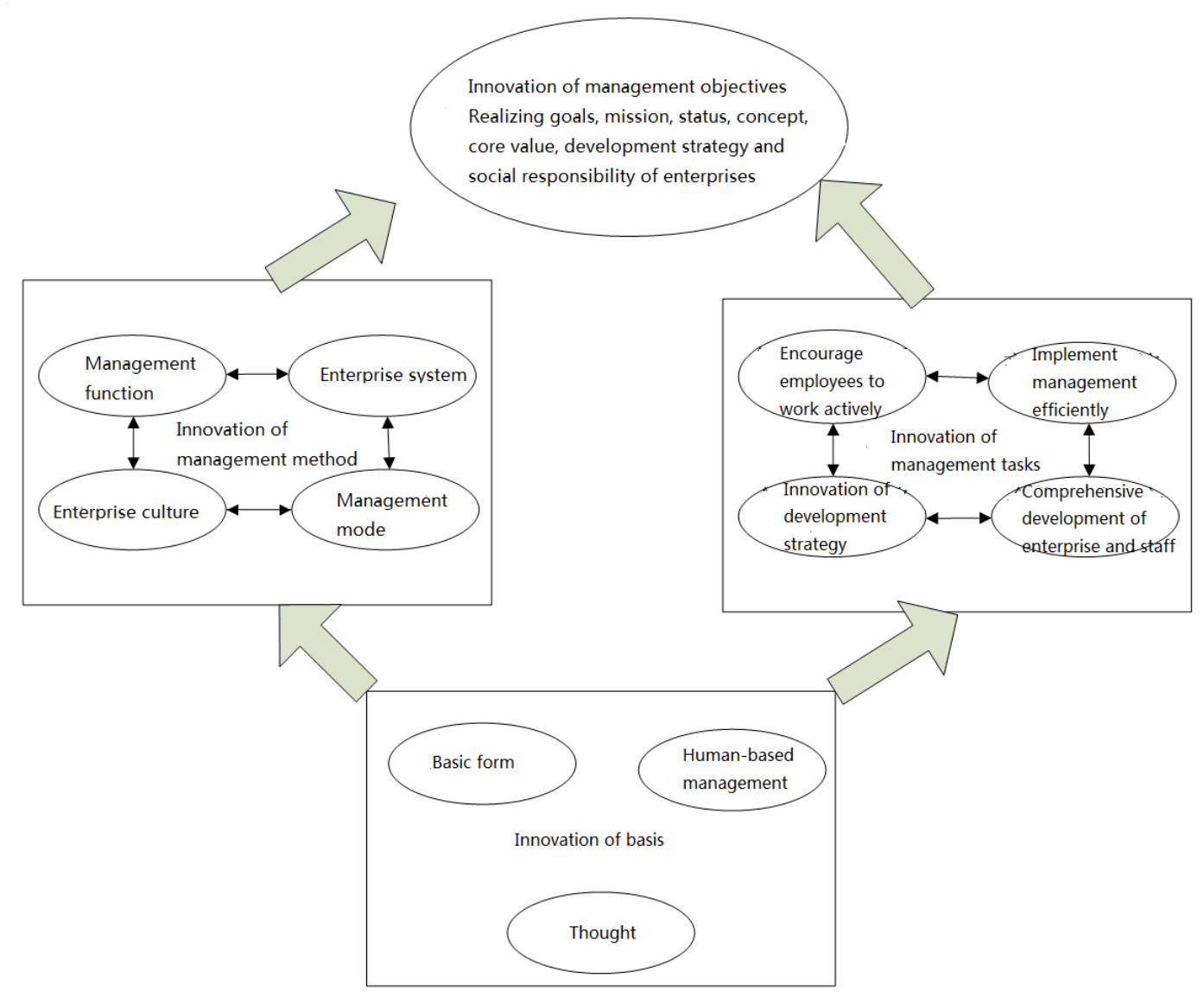

Figure 1. The innovative management mode of enterprise.

After adopting the innovative management mode and measures, the products sales, income level, profit margin and output value of this enterprise have been comprehensively improved as showed in Fig. 2 below. Therefore, the innovative enterprise management produces a marked effect.

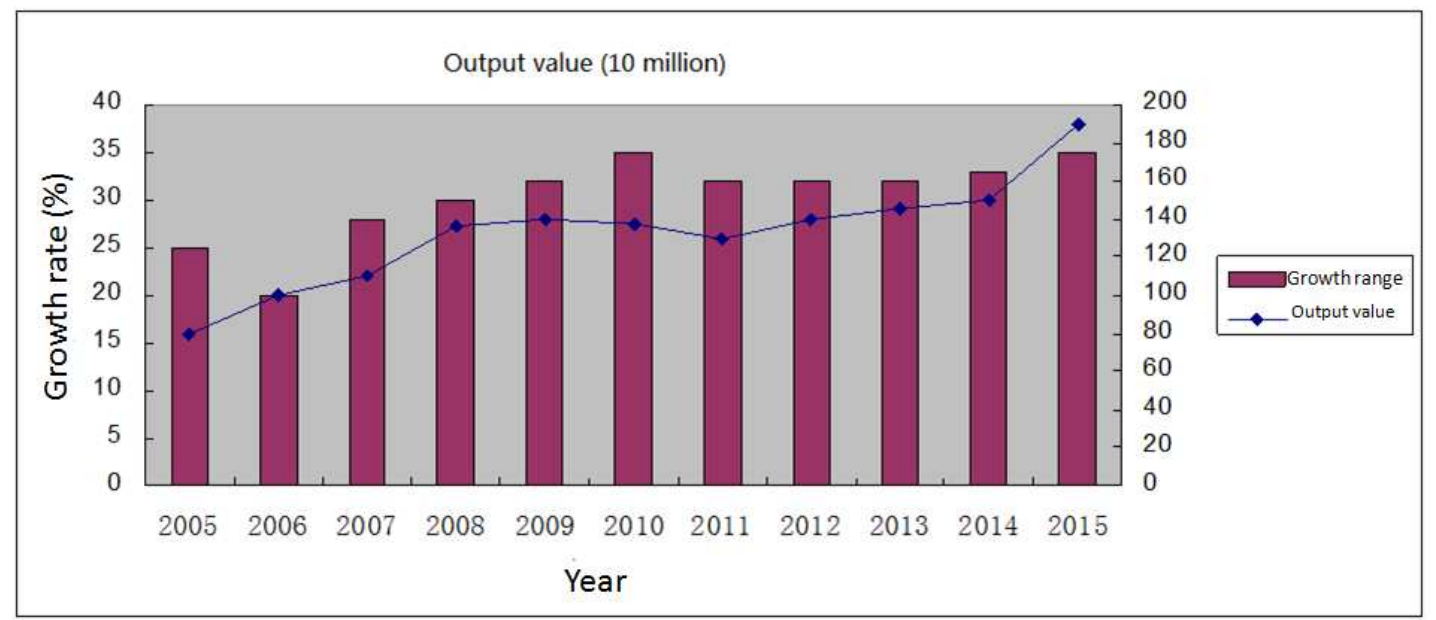

Figure 2. The output value and its growth in the 10 years after the implementation of innovation management.

\section{Conclusions}

This article focuses on the necessity, development experience, current situation and problems of enterprises management innovation, analyses all kinds of key issues existing in the innovation of domestic enterprises management, and, meanwhile, gives specific suggestions for different 
problems. This article suggests that the innovation of modern enterprises must be established based on comprehensive strategic approach, scientific concept of development, sound organizational structure, all-around technology and advancement, and also sound enterprise management system, and innovations and reforms should be carried out by combining the actual situations of the enterprises at the same time. In addition, the study has proved the great changes brought by the innovation of enterprises management by an innovation case of a diesel factory in Shandong. The author hopes that the analysis of the key problems and suggestions for the innovation of enterprises management in this study can provide guidance for domestic large and medium-sized enterprises in their development process.

\section{References}

[1] N. Yan, Research on problems of enterprises management innovation, Guizhou Univ. (2013) 06.

[2] H.W. Tian, Research on the innovation of Chinese domestic enterprises management, Changchun Univ. Sci. Technol. (2015) 07.

[3] T. Xu, Research on the innovation of Chinese domestic enterprises management, Central China Normal Univ. (2014) 06.

[4] T.M. Lu, On the key problems of enterprises management innovation, Inquiry Into Economic Issues. 146 (2012) 23-28.

[5] S, Goh, G. Richards, Benchmarking the learning capability of organizations, Eur. Manag. J. 5 (1997) 575-583.

[6] F.F. Wang, Project management system research of QHD Tolian Company, Yanshan Univ. 12 (2012).

[7] Y.J. Li, LB. Bai, Research on creating organization model for enterprise order project management, Pro. Manag. Technol. 10 (2011) 103-107.

[8] Y.H. Deng, A research on the project management system of communication enterprise, Pro. Manag. Technol. 11 (2010) 53-56. 